\title{
Phenotype and fertilizing capacity of spermatozoa of chimaeric mice produced from two strains that differ in sperm quality
}

\author{
H. Krzanowska, B. Wabik-Śliz and J. Rafiǹski* \\ Department of Genetics and Evolution and * Department of Comparative Anatomy, Institute of \\ Zoology, Jagiellonian University, Karasia 6, 30-060 Kraków, Poland
}

\begin{abstract}
Summary. Spermatozoa of males from the inbred mouse strains, KE (albino) and CBA (agouti), are distinguishable by head shape and differ in quality: CBA spermatozoa show a lower percentage of abnormal heads and higher efficiency of fertilization. Aggregation chimaeras were produced to investigate whether these differences are intrinsic or extrinsic to spermatogenic cells. Among 24 overt chimaeras, 14 were males: 1 was sterile, 8 produced either KE or CBA spermatozoa, as recognized by shape and by progeny testing, and $5(21 \%)$ were germ-line chimaeras. Both the level of abnormal sperm heads and the efficiency of fertilization of CBA and KE spermatozoa produced by chimaeric males (except two subfertile ones) were within the range characteristic for the respective strain. All 5 germ-line chimaeras, irrespective of their coat colour composition, produced about $98 \% \mathrm{KE}$ and only $2 \%$ CBA spermatozoa, which indicated strong selection against CBA germ cells. However, mature CBA spermatozoa showed high competitive ability, because the proportion of agouti progeny (from the CBA component) sired by those males was significantly higher than the proportion of CBA spermatozoa, estimated from vaginal plug preparations after every mating. The fact that this difference was particularly striking for one chimaera with a preponderance of CBA somatic component may suggest some influences extrinsic to spermatogenic cells.

We conclude from this study that sperm head shape, the level of sperm abnormalities and fertilizing capacity are determined largely autonomously by genes acting in the germ cells. The internal environment created by foreign somatic cells exerts only minor modifications, unless there has been deterioration beyond the range of 'normality'.
\end{abstract}

Keywords: mouse; chimaera; sperm abnormalities; sperm competition; germ cell selection

\section{Introduction}

Sperm phenotype develops during the course of spermatogenesis under the control of many genes which, theoretically, may be acting within the germ cells or within the surrounding somatic cells (review: Handel, 1987). Both possibilities were revealed in experiments with aggregation chimaeras composed of normal and male-sterile mutant cells. Two different mutations, $\mathrm{p}^{\mathrm{H} 6}$ and $\mathrm{qk}$, affecting sperm structure and causing sterility, showed autonomy of function of respective genes within spermatogenic cells (Handel et al., 1987), while somatic (probably Sertoli) cell defects were implicated in germ cell degeneration and sterility of $\mathrm{Tfm}$ (Lyon et al., 1975) and of Sl/Sld mutants (Nakayama et al., 1988).

To our knowledge there has been only one published work in which this problem is analysed in relation to genetic differences between normal sperm phenotypes. Using appropriate chimaeras, Burgoyne (1975) showed that interstrain differences in the dimensions of spermatozoa from C57BL 
and $\mathrm{C} 3 \mathrm{H} / \mathrm{Bi}$ mouse strains are due to genes expressed through the germ line. However, it is still not known whether the same applies to differences in functional capacity of spermatozoa.

We attempted to answer this question by analysing $\mathrm{KE} \leftrightarrow \mathrm{CBA}$ aggregation chimaeras, because spermatozoa of males from KE and CBA strains are distinguishable by their characteristic shapes, and differ significantly in the percentage of abnormal heads and in efficiency of fertilization, especially in competitive conditions (Krzanowska, 1969, 1970, 1981, 1986). The aim of this study was to find out whether KE and CBA spermatozoa produced by chimaeric males possess characteristic features of their respective strains or undergo modification under the influence of the foreign somatic cells.

\section{Materials and Methods}

Animals. The two inbred strains used to construct aggregation chimaeras, $\mathrm{CBA} / \mathrm{Kw}$ (subsequently referred to as $\mathrm{CBA}$ ) and KE, differ in coat colour and carry different structural alleles for the enzyme glucosephosphate isomerase (GPI-1: EC 5.3.1.9). CBA mice are agouti (CCAABB) and express the B alloenzyme of GPI-1, while KE are albino (ccaabb) and express the A alloenzyme (Rafinski \& Krzanowska, 1985). Nonagouti, black $(\mathrm{C} 57 \mathrm{BL} / \mathrm{Kw} \times \mathrm{KP}) \mathrm{F}_{1}$ females (subsequently referred to as $\mathrm{F}_{1}$; genotype $\mathrm{CCaaBb}$ ) or females born to $\mathrm{F}_{1}$ mothers mated to $\mathrm{KE}$ males $\left(\mathrm{F}_{1} \times \mathrm{KE}\right)$ were used as embryo foster mothers. Only $F_{1}$ females were used for progeny testing of chimaeric males. Females of an outbred stock (maintained in our Department for 70 generations with maximum avoidance of inbreeding) were mated with chimaeric males for testing fertilizing capacity of their spermatozoa.

Production of chimaeras. To compensate for the slow development of CBA embryos, the following time schedule was adopted. CBA females were injected with 5 i.u. PMSG and 53-62 h later with 5 i.u. hCG, then mated with a CBA male and killed about $77 \mathrm{~h}$ after hCG injection, yielding 8-cell embryos. Because KE mice responded poorly to gonadotrophins, pro-oestrous females were mated overnight with a KE male (vaginal plug on Day 1) and killed at about 14:00 h on Day 3, yielding 4-8-cell embryos. Initially 8-cell CBA and KE embryos were aggregated, but when it became obvious that in one-sex chimaeras there is shortage of CBA germ cells (possibly because of their slower development) 4-cell KE embryos were also used. Chimaeras were produced essentially as described by Bowman \& McLaren (1970) with slight modifications. Briefly, embryos were aggregated in buffered M-2 medium (Fulton \& Whittingham, 1978) after removal of the zona pellucida with acidified Tyrode's solution ( $\mathrm{pH} 2.5$ ). Subsequently, the aggregated embryos were cultured in Medium M-16 (Whittingham, 1971) containing bovine serum albumin $(4 \mathrm{mg} / \mathrm{ml})$, at $37^{\circ} \mathrm{C}$ in a humidified atmosphere containing $5 \% \mathrm{CO}_{2}$ for $24 \mathrm{~h}$. The resulting chimaeric morulae or blastocysts were transferred to the uterus of a 3.5 day post coitum pseudopregnant $F_{1}$ or $F_{1} \times \mathrm{KE}$ female. In some cases when only a few fused embryos were available, single KE or CBA embryos were also transferred to the same recipient.

Testing of chimaeras. Throughout their lives, male chimaeras were mated with 3-5-month-old $F_{1}$ females once or twice weekly, if possible, to produce progeny. Usually pro-oestrous females were caged overnight with a male, but in some cases oestrous females were paired only between 09:00 and 12:00 h (delayed matings). To obtain a sperm sample at each insemination, several hours after mating the copulation plug was removed and its internal surface (facing the cervix) was pressed firmly against the slide and smeared. The preparation was dried in air, fixed in acetic alcohol, dried and stained with eosin Y. Usually 1000 spermatozoa of normal shape (or separated sperm heads) per smear were inspected under the microscope to evaluate the proportion of CBA and KE sperm heads, as recognized by their shapes (Krzanowska, 1986). Abnormal spermatozoa were not included in this calculation because not all of them could be classified with certainty. Sperm abnormalities were analysed according to previous classification (Krzanowska, 1981). The mean percentage of abnormalities was calculated for every male from 3 samples collected between 3 and 6 months of life. Litter size was estimated on the day of birth and 7 days later the young were scored for pigmentation: animals born from eggs fertilized by the CBA spermatozoa were agouti coloured, while those fertilized by the KE spermatozoa were black or brown.

To estimate the efficiency of fertilization, outbred females were individually caged overnight with chimaeric males and killed 1 day after copulation. Ova flushed from the oviducts were examined. Two-cell ova with clearly visible nuclei were counted as fertilized. One-cell ova, if present, were fixed in acetic alcohol and stained with toluidine blue; all were found to be in metaphase II of meiosis and thus were counted as unfertilized.

Estimation of glucosephosphate isomerase alloenzymes. Alloenzymes of GPI were analysed in the samples of heart, kidney, liver and testes of all germ-line chimaeras. Standard methods of horizontal starch electrophoresis were used. Tissue samples were first frozen and then homogenized manually in an equal volume of Tris- $\mathrm{HCl}-\mathrm{Na}_{2} \mathrm{EDTA}$ buffer $\mathrm{pH}=6.8$ (Selander $e t$ al., 1971). Crude homogenates were then absorbed onto filter paper wicks and these were inserted into the gel. Electrophoresis was conducted for $4-5 \mathrm{~h}$ at $2-4^{\circ} \mathrm{C}$ and constant $50 \mathrm{~mA}$. Tris-citrate buffer $\mathrm{pH}=7.0$ was used for gels and electrodes (Shaw \& Prasad, 1970). After electrophoresis the gel was cut into horizontal slices and stained for GPI activity according to the method of Harris \& Hopkinson (1976). Activities of A and B forms were evaluated visually. 
Chimaera No. 60 was subjected to unilateral orchidectomy when 6 months of age. GPI was analysed for a sperm sample expressed from the cauda epididymidis and for testis cells. The latter were isolated using trypsin and collagenase digestion and filtration, according to the Kierszenbaum \& Tres (1981) technique, then suspended in Eagle's minimum essential medium (MEM) and incubated in culture dishes at $33^{\circ} \mathrm{C}$ for $5.5 \mathrm{~h}$, allowing Sertoli cells to settle at the bottom. A longer culture time was not attempted to avoid any possible differences in survival of KE and CBA Sertoli cells. From the bottom and top fractions small samples were collected, dried on the slide, fixed in acetic alcohol and stained with toluidine blue to estimate the proportion of Sertoli cells, as recognized by a pale nucleus with two (sometimes one) strongly stained blocks of heterochromatin adjacent to the nucleolus (Fig. 5). The bottom fraction, enriched in Sertoli cells (about 1 Sertoli cell per 20 germ cells), and the top fraction, practically devoid of them, were analysed separately for GPI.

\section{Results}

\section{Characteristics of chimaeras}

Among 35 young born to females which received only fused embryos, there were 9 agouti (CBA), 4 albino (KE) and 22 overt chimaeras $(63 \%)$ with coats composed of various proportions of albino and agouti patches. Altogether, 24 chimaeras were produced, $58 \%$ of them males. Females were characterized by more extreme coat colour compositions than males (Table 1). One female with $41 \%$ of $X Y$ cells was sterile, 3 others with some $X Y$ cells and coat containing $>90 \%$ of agouti hair produced only CBA progeny, and the remaining ones produced only KE progeny (Lenartowicz et al., 1988; B. Wabik-Śliz, unpublished results).

Table 1. Composition of coat colours and type of progeny produced by $\mathrm{KE} \leftrightarrow \mathrm{CBA}$ chimaeras

\begin{tabular}{|c|c|c|c|c|c|c|c|}
\hline \multirow{3}{*}{$\begin{array}{l}\% \text { of } \\
\text { CBA coat }\end{array}$} & \multicolumn{3}{|c|}{ Females } & \multicolumn{4}{|c|}{ Males } \\
\hline & \multirow[b]{2}{*}{ Sterile } & \multicolumn{2}{|c|}{$\begin{array}{l}\text { Producing progeny } \\
\text { from component }\end{array}$} & \multirow[b]{2}{*}{ Sterile } & \multicolumn{3}{|c|}{$\begin{array}{l}\text { Producing progeny } \\
\text { from component }\end{array}$} \\
\hline & & $\mathrm{KE}$ & CBA & & $\mathrm{KE}$ & $\mathrm{KE}+\mathrm{CBA}$ & CBA \\
\hline$<5$ & & 1 & & & & & \\
\hline 10 & & 1 & & & & & \\
\hline 20 & & 1 & & & & 1 & \\
\hline 30 & & $i$ & & & & 1 & \\
\hline $40-60$ & $1^{*}$ & 2 & & & $3\left(2^{*}\right)$ & 2 & $1^{*}$ \\
\hline $\begin{array}{l}70 \\
80\end{array}$ & & & & $1^{*}$ & 1 & & $1^{*}$ \\
\hline $\begin{array}{l}80 \\
90\end{array}$ & & & $1^{*}$ & 1 & & 1 & 2 \\
\hline$>95$ & & & $2^{*}$ & & & & \\
\hline Total & 1 & 6 & 3 & 1 & 4 & 5 & 4 \\
\hline
\end{tabular}

${ }^{*}$ Karyotyped as $\mathrm{XX} \leftrightarrow \mathrm{XY}$ chimaera (Lenartowicz et al., 1988; and unpublished data).

Only males were investigated in this study (Tables 1 and 2). Five of them were germ-line chimaeras (XY $\leftrightarrow \mathrm{XY}$ ) producing progeny both from CBA and KE components, but predominantly from the latter (Table 4). Among the 8 males siring only one type of progeny, 4 were karyotyped as $\mathrm{XY} \leftrightarrow \mathrm{XX}$ with predominance of XY cells; one of them (No. 2) became sterile in the 8th month of life and another one (No. 14) had only a few spermatozoa at autopsy in the 9th month of life (both produced progeny from the CBA component). The remaining male (No. 1) possessed $54 \%$ of XY CBA cells and $46 \%$ of XX KE cells, as recognized by C-band pattern, was completely sterile producing vaginal plugs devoid of spermatozoa, and at autopsy at 12 months of age showed severe degeneration in testicular tubules and lack of spermatogenesis (Lenartowicz et al., 1988). 
Table 2. Characteristics of $\mathrm{KE} \leftrightarrow \mathrm{CBA}$ male chimaeras

\begin{tabular}{|c|c|c|c|c|c|c|}
\hline $\begin{array}{l}\text { Male } \\
\text { No. }\end{array}$ & $\begin{array}{l}\% \text { of } \\
\text { CBA } \\
\text { coat }\end{array}$ & $\begin{array}{l}\text { No. of } \\
\text { litters } \\
\text { sired }\end{array}$ & $\begin{array}{l}\text { Spermatozoa and } \\
\text { progeny from } \\
\text { component }\end{array}$ & Karyotype* & $\begin{array}{c}\text { Age at } \\
\text { killing } \\
\text { (months) }\end{array}$ & Notes \\
\hline 1 & 80 & - & - & $46 \% \mathrm{XX}$ & 12 & Sterile matings \\
\hline 2 & 80 & 5 & CBA & $11 \% X X$ & 11 & Sterile from 8 months \\
\hline 14 & 50 & 9 & CBA & $28 \% \mathrm{XX}$ & 9 & $\begin{array}{l}\text { Few spermatozoa in vasa } \\
\text { deferentia }\end{array}$ \\
\hline 31 & 90 & 7 & CBA & - & 5 & \\
\hline 20 & 90 & - & $\mathrm{CBA} \dagger$ & - & - & Died after 3 months \\
\hline 13 & 70 & 8 & $\mathrm{KE}$ & - & 9 & \\
\hline 15 & 50 & 6 & KE & $17 \% \mathrm{XX}$ & 9 & \\
\hline 22 & 60 & 9 & KE & - & 8 & \\
\hline 61 & 50 & 5 & KE & $26 \% X X$ & 7 & \\
\hline 19 & 20 & 6 & $\mathrm{KE}+\mathrm{CBA}$ & $X Y \leftrightarrow X Y$ & - & Died after 3 months \\
\hline 42 & 50 & 33 & $\mathrm{KE}+\mathrm{CBA}$ & $X Y \leftrightarrow X Y$ & 13 & \\
\hline 45 & 30 & 32 & $\mathrm{KE}+\mathrm{CBA}$ & $\mathrm{XY} \leftrightarrow \mathrm{XY}$ & 11 & \\
\hline 46 & 40 & 34 & $\mathrm{KE}+\mathrm{CBA}$ & $X Y \leftrightarrow X Y$ & 11 & \\
\hline 60 & 90 & 17 & $\mathrm{KE}+\mathrm{CBA}$ & $\mathrm{XY \leftrightarrow XY}$ & 9 & \\
\hline
\end{tabular}

*Proportion of XX cells in the bone marrow preparations (from Lenartowicz et al., 1988; for chimaera No. 61. unpublished).

†Estimated only for spermatozoa.

\section{Analysis of spermatozoa}

As shown previously (Krzanowska, 1986), heads of CBA spermatozoa have different curvature of the dorsal contour than do KE spermatozoa, and possess characteristic invagination in the apical part (Figs $1 \& 2$ ). The same characteristic shapes were easily recognized in normal spermatozoa of chimaeric mice (Figs $3 \& 4$ ), and in every case the type of spermatozoa (KE or/and CBA) was concordant with the type of progeny produced by the given male (Table 2 ).

Table 3 shows mean proportions of abnormal sperm heads produced by 20 control males from each strain, by apparently non-chimaeric males born from aggregated and transferred embryos and by chimaeras. KE spermatozoa were characterized by a significantly higher abnormality level than CBA spermatozoa, irrespective of the group of males, and no significant differences between chimaeric and normal males were found in this respect. Even in the males producing both types of spermatozoa (about $2 \% \mathrm{CBA}$ and $98 \% \mathrm{KE}$ with normal shape), the proportion of abnormalities was not significantly different from that in KE males; among abnormal forms the majority could be

Fig. 1. Sperm heads from the vas deferens of a mouse of the KE strain. Bar $=10 \mu \mathrm{m}$.

Fig. 2. Sperm heads from the vas deferens of a mouse of the CBA strain; characteristic invagination is arrowed.

Fig. 3. Spermatozoa from the vaginal plug formed by a germ-line chimaera $\mathrm{KE} \leftrightarrow \mathrm{CBA}$; besides many KE spermatozoa, one with a typical CBA sperm head is seen (arrow). Bar $=10 \mu \mathrm{m}$.

Fig. 4. Enlarged fragment from Fig. 3; CBA sperm head arrowed.

Fig. 5. Preparation of testis tubule cells of chimaera No. 60; fraction enriched in Sertoli cells (arrows), stripped from the bottom of a dish after $5 \cdot 5 \mathrm{~h}$ of culture (see 'Material and Methods'). Toluidine blue staining. Bar $=10 \mu \mathrm{m}$.

Fig. 6. Electrophoretogram of GPI-1 isoenzymes (A, B) from testis tubule fractions (I, II) and spermatozoa from the cauda epididymidis (III) of Chimaera 60. I, bottom fraction enriched in Sertoli cells (shown in Fig. 5); II, top fraction devoid of Sertoli cells. In I, a clear B band is seen while in II and III there are only traces of this band. 

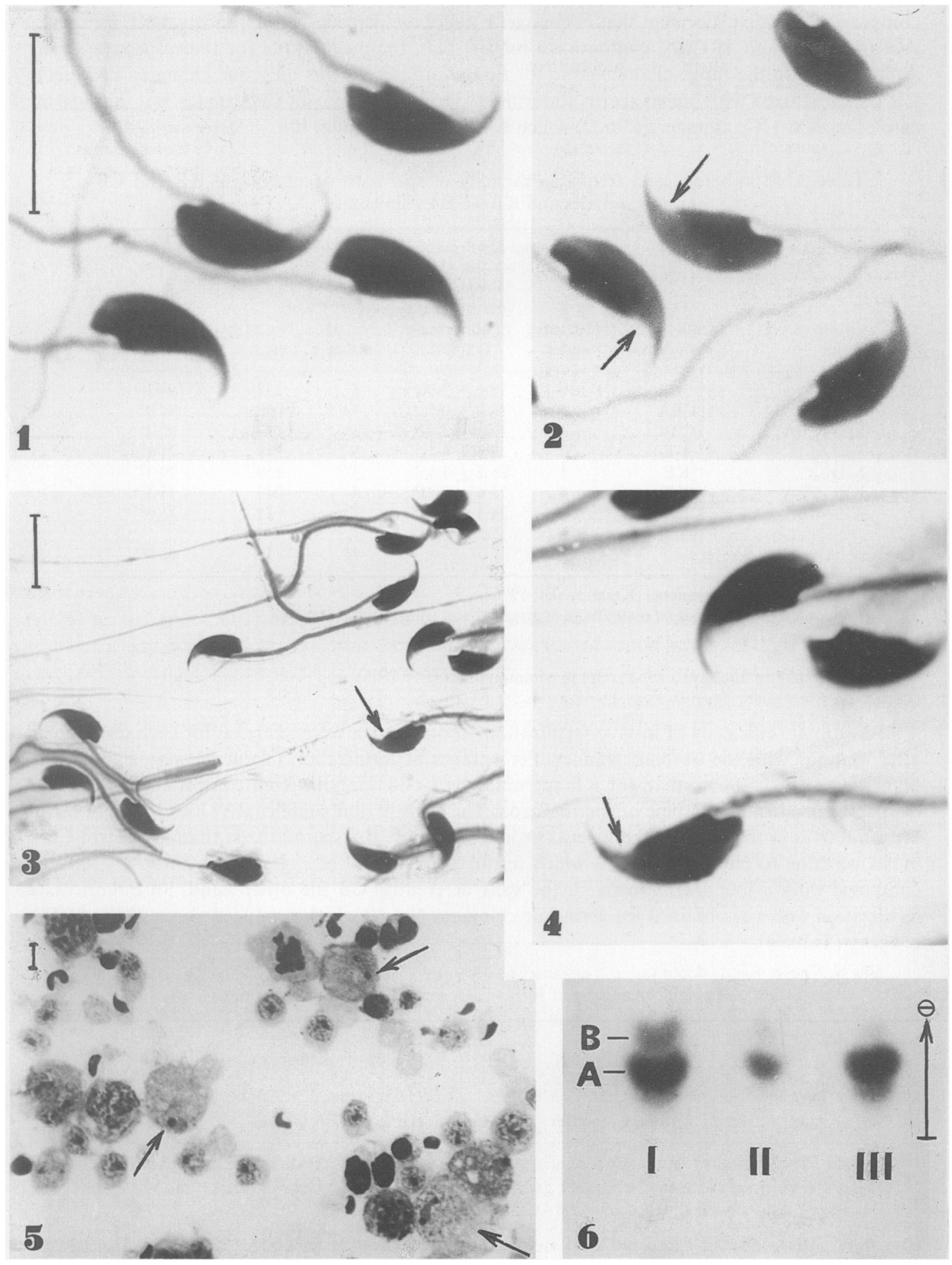
classified as belonging to the KE strain. On the other hand, if distributions of abnormality levels are compared (Fig. 7), it is evident that in chimaeric males the percentages of abnormal KE spermatozoa are lower, and of CBA spermatozoa higher, than the mean value for the respective strain, although within the range characteristic for that strain. There was only one chimaera producing CBA spermatozoa with higher sperm abnormality level than in any of CBA males, but this was the case of an $\mathrm{XX} \leftrightarrow \mathrm{XY}$ chimaera (No. 2) which became sterile in later life.

Table 3. Morphology and fertilizing capacity of spermatozoa of control KE and CBA males and $\mathrm{KE} \leftrightarrow \mathrm{CBA}$ chimaeras

\begin{tabular}{|c|c|c|c|c|c|c|}
\hline \multirow[b]{2}{*}{$\begin{array}{l}\text { Group of } \\
\text { males }\end{array}$} & \multirow[b]{2}{*}{$\begin{array}{l}\text { Genotype of } \\
\text { spermatozoa }\end{array}$} & \multicolumn{2}{|c|}{ Sperm head abnormalities } & \multicolumn{3}{|c|}{ Fertilization of outbred females } \\
\hline & & $\begin{array}{l}\text { No. of } \\
\text { males }\end{array}$ & $\begin{array}{c}\text { Proportion } \\
\text { (mean } \pm \text { s.d.) } \\
\text { of abnormals } \\
\text { (angles) }\end{array}$ & $\begin{array}{l}\text { No. of } \\
\text { males }\end{array}$ & $\begin{array}{l}\text { No. of } \\
\text { eggs }\end{array}$ & $\begin{array}{c}\% \text { of } \\
\text { fertilization }\end{array}$ \\
\hline CBA* & CBA & 20 & $13 \cdot 5 \pm 2 \cdot 00^{\mathrm{a}}$ & 5 & 237 & $94 \cdot 1^{\mathrm{c}}$ \\
\hline $\mathrm{CBA} \dagger$ & CBA & 5 & $14.0 \pm 0.51^{\mathrm{a}}$ & 1 & 50 & $96 \cdot 0^{\mathrm{c}}$ \\
\hline $\mathrm{KE} \leftrightarrow \mathrm{CBA}$ & $\mathrm{CBA}$ & 4 & $16.3 \pm 2.92^{\mathrm{a}}$ & 3 & 177 & $90 \cdot 4^{c}$ \\
\hline $\mathrm{KE}^{*}$ & $\mathrm{KE}$ & 20 & $27 \cdot 8+4.27^{\mathrm{b}}$ & 5 & 249 & $71 \cdot 1^{\mathrm{d}}$ \\
\hline $\mathrm{KE} \dagger$ & $\mathrm{KE}$ & 3 & $26.2 \pm 3.35^{\mathrm{b}}$ & 3 & 150 & $79 \cdot 3^{\text {de }}$ \\
\hline $\mathrm{KE} \leftrightarrow \mathrm{CBA}$ & $\mathrm{KE}$ & 4 & $25 \cdot 0 \pm 2.71^{\mathrm{b}}$ & 4 & 247 & $73 \cdot 3^{\mathrm{de}}$ \\
\hline \multirow[t]{2}{*}{$\mathrm{KE} \leftrightarrow \mathrm{CBA}$} & $\begin{array}{l}\text { KE:CBA } \\
(98: 2)\end{array}$ & 5 & $24.3 \pm 1.65^{b}$ & $1 \ddagger$ & 52 & $75 \cdot 0^{\text {de }}$ \\
\hline & & & & $1 \S$ & 50 & $86 \cdot 0^{\text {ce }}$ \\
\hline
\end{tabular}

*From previous experiments (Krzanowska, 1976).

†Apparently non-chimaeric males from aggregated and transferred embryos.

†Chimaera 42.

\$Chimaera 60.

Means that do not have a superscript in common differ $(P<0.05)$.

To estimate efficiency of in-vivo fertilization, about 50 ova were analysed for each tested male after matings with the outbred females. Percentages of fertilization (Table 3) were significantly higher for CBA $(>90 \%)$ than for KE spermatozoa $(<80 \%)$, both from control males and from chimaeras producing one type of spermatozoa. The slightly (not significantly) lower level of fertilization $(90 \%)$ in the group of chimaeras producing only CBA spermatozoa than in control CBA males was due to chimaera No. 14 which fertilized only $78 \%$ of eggs, but at autopsy (Table 2) contained only a few spermatozoa in the vasa deferentia. On the other hand, an intermediate fertilization rate was obtained for germ-line chimaera No. 60 which produced about $20 \%$ of CBA progeny (Table 4).

Table 4. Analysis of $\mathrm{KE} \leftrightarrow \mathrm{CBA}$ germ line chimaeric males

\begin{tabular}{|c|c|c|c|c|c|c|c|c|c|c|}
\hline \multirow{3}{*}{$\begin{array}{l}\text { Male } \\
\text { No. }\end{array}$} & \multirow{3}{*}{$\begin{array}{l}\% \text { of } \\
\text { CBA } \\
\text { coat }\end{array}$} & \multirow{2}{*}{\multicolumn{4}{|c|}{ GPI-1 isoenzymes* }} & \multirow{2}{*}{\multicolumn{2}{|c|}{$\begin{array}{c}\text { Mean } \% \text { of spermatozoa } \\
\text { classified as }\end{array}$}} & \multicolumn{3}{|c|}{ Progeny } \\
\hline & & & & & & & & \multirow{2}{*}{$\begin{array}{l}\text { Total } \\
\text { no. }\end{array}$} & \multicolumn{2}{|c|}{ Agouti } \\
\hline & & Heart & Kidney & Liver & Testis & KE & CBA (range) & & No. & $\%$ \\
\hline 19 & 20 & - & - & - & - & 97.8 & $2 \cdot 2(1 \cdot 0-3 \cdot 0)$ & 24 & 1 & $4 \cdot 2$ \\
\hline 45 & 30 & 3 & 2 & 0 & 1 & 98.2 & $1.8(0.5-3.0)$ & 268 & 11 & $4 \cdot 1$ \\
\hline 46 & 40 & 4 & 2 & 0 & 1 & $98 \cdot 6$ & $1.4(0.4-3.0)$ & 294 & 12 & $4 \cdot 1$ \\
\hline 42 & 50 & 4 & 4 & 3 & 2 & 97.5 & $2.5(1.4-4.5)$ & 280 & 11 & 3.9 \\
\hline 60 & 90 & 5 & 5 & 5 & 3 & $97 \cdot 2$ & $2.8(1.8-4.5)$ & 178 & 37 & $20 \cdot 8$ \\
\hline
\end{tabular}

*0, only KE variant (GPI-1A) detected; 1, KE and traces of CBA (GPI-1B); 2, KE much stronger than CBA; 3, KE stronger than $\mathrm{CBA} ; 4, \mathrm{KE}=\mathrm{CBA} ; 5, \mathrm{CBA}$ stronger than $\mathrm{KE}$. 


\section{Sperm competition in germ-line chimaeras}

All 5 germ-line chimaeras, irrespective of their coat pigmentation, produced predominantly KE spermatozoa, as recognized by their shape (Table 4; Fig. 3). The percentage of CBA spermatozoa in sperm samples collected from vaginal plugs at each mating, oscillated between 0.4 and $4.5 \%$ (mean $2 \cdot 1 \%$ ) throughout the whole life of each male. Similar proportions were found in the left and right vasa deferentia, when tested after killing the males. Except for male No. 19, which died when 3 months old, the other chimaeras mated frequently with $F_{1}$ females and sired large litters (mean litter size $>8$ young), composed predominantly of non-agouti young, i.e. derived from the KE germ-line cells.

For chimaeras Nos 42, 45 and 46, tested until the age of 11-13 months, the number of agouti progeny (i.e. developed from eggs fertilized by CBA spermatozoa) oscillated between 0 and 2 per litter, amounting to $4 \%$ in the mean. This proportion did not change with the age of the male: of 11-12 agouti young sired by each of those males (Table 4), only 5-6 were born during the first 6 months of testing. There was no correlation between the percentage of CBA spermatozoa recovered from the vaginal plug and the number of agouti young born in the resulting litter. The proportion of agouti progeny from overnight pairings was not significantly different from those from delayed matings.

On the assumption that each spermatozoon of normal shape had an equal chance of fertilizing an egg (abnormal forms were usually prevented from reaching the oviduct; Krzanowska, 1986), the proportion of agouti young should equal the calculated proportion of CBA spermatozoa, i.e. $1.93 \%$ for the three mentioned chimaeras. Thus, among 842 young sired by those males, the expected proportion of agouti to non-agouti progeny amounts to $16: 826$, which is significantly less than the actual proportion obtained, 34:808 $\left(\chi^{2}=19.8 ; P<0.01\right)$. This indicates a higher competitive ability of CBA spermatozoa.

This difference in competitive ability was even more pronounced for chimaera No. 60 which produced $3 \%$ of CBA spermatozoa but sired as many as $21 \%$ of agouti progeny (Table 4 ). Although only 178 young were born, the obtained ratio of agouti to non-agouti progeny (37:141) was significantly higher than expected $\left(5: 173 ; \chi^{2}=210.7 ; P<0.01\right)$ than that obtained for the other germ-line chimaeras $\left(\chi^{2}=61 \cdot 1 ; P<0.01\right)$. The removal of one testis did not change the proportion of agouti progeny.

The analysis of coat pigmentation and of GPI alloenzymes in some organs (Table 4) indicates that, except in male No. 60, in all other germ-line chimaeras the CBA somatic cells were in the minority in comparison with KE cells. (Equal activities of both forms of alloenzymes were scored only for heart and kidney but, as revealed by the analysis of (CBA $\times \mathrm{KE}) \mathrm{F}_{1}$ hybrid mice, in those two organs the expression of GPI-1B alloenzyme is higher than that of GPI-1A form; J. Rafiński \& H. Krzanowska, unpublished observations). To compare the genetic composition of somatic and germ cells in the gonads of male No. 60 before his senescence, the right testis was removed in the 6th month of life. In the fraction enriched in Sertoli cells (bottom fraction of incubated testis tubule cells, Fig. 5; see 'Materials and Methods'), a GPI-1B band, characteristic of the CBA strain was clearly visible in addition to a strong GPI-1 A band, while in the top fraction, practically devoid of somatic cells, and in a sperm sample from the cauda epididymidis, only traces of the GPI-1B alloenzyme could be seen (Fig. 6). These results confirm that germ cells of Male 60 were derived predominantly from the KE component, and indicate that a considerable proportion of Sertoli cells of that male was derived from the CBA strain.

\section{Discussion}

In an earlier study it was shown that KE and CBA spermatozoa are distinguishable by head shape so that their proportions could be reliably estimated in a sperm mixture (Krzanowska, 1986). In the present experiments the typical shapes of KE and CBA sperm heads were easily recognized in 


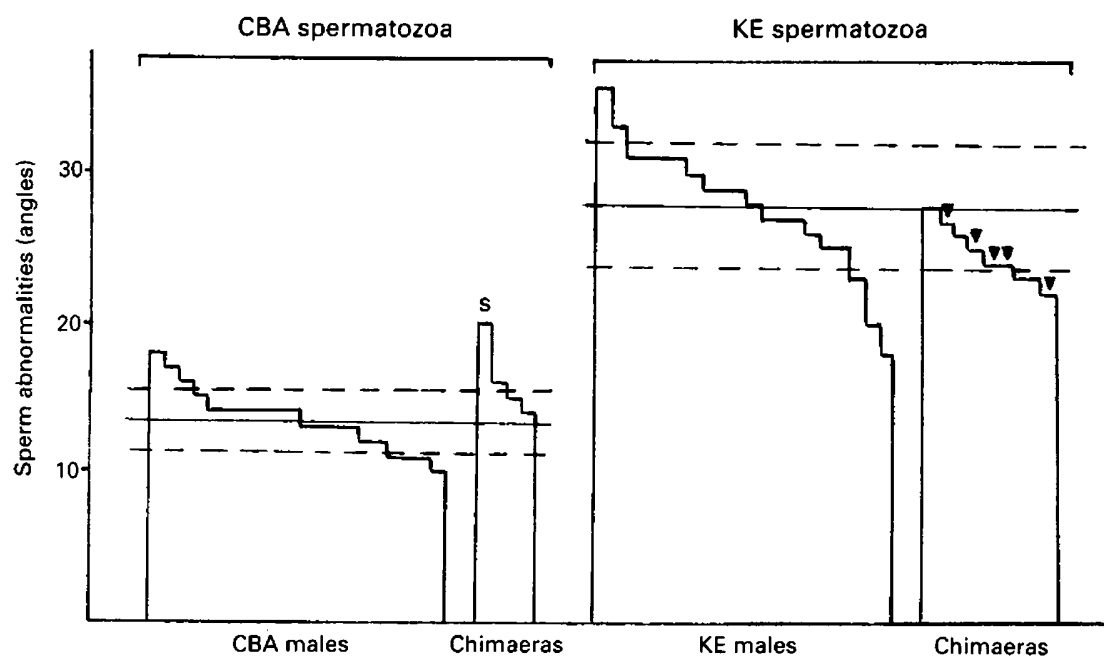

Fig. 7. Frequency distribution of sperm head abnormalities (percentages in angular transformation) in CBA and KE spermatozoa produced by 20 control males from each strain and by $\mathrm{KE} \leftrightarrow \mathrm{CBA}$ chimaeras. Arrows point to samples produced by 5 germ-line chimaeras $(98 \%$ $\mathrm{KE}+2 \% \mathrm{CBA}$ spermatozoa); $\mathrm{s}$, sample of semisterile Chimaera 2 . The horizontal (mean) and broken lines (s.d.) refer to control males.

preparations from spermatozoa of chimaeric males, both of $\mathrm{XX} \leftrightarrow \mathrm{XY}$ and $\mathrm{XY} \leftrightarrow \mathrm{XY}$ constitution and the correct classification of sperm type of a given male was confirmed by progeny testing. These results support earlier findings of Burgoyne (1975) that sperm shape is determined by genes expressed through the germ line.

The possibility of recognizing KE and CBA spermatozoa by their shape permitted testing whether their quality and fertilizing capacity were modified in chimaeric males, which was the main purpose of this study. Theoretically, one could expect some effects caused by the whole internal environment of the chimaeric male, as well as influences of the somatic component of the testis itself. In particular, the Sertoli cells may be important in this respect, assuming that in the chimaeric gonad genetically different germ cells can associate with them. Supplying nutrient molecules and metabolic intermediates to germ cells (Grootegoed et al., 1985), Sertoli cells regulate the outcome of spermatogenesis and thus may influence sperm quality. However, any possible effects exerted by the foreign genotype of Sertoli cells could be proved only in XY $\leftrightarrow \mathrm{XY}$ chimaeras (in our study only in 5 germ-line chimaeras), because Sertoli cells are recruited only from the XY cells (Burgoyne et al., 1988) and thus in $\mathrm{XX} \leftrightarrow \mathrm{XY}$ chimaeras they develop from the same genetic component as sperm cells.

Unfortunately, the scope of our investigations has been considerably limited by the fact that all germ-line chimaeras, irrespective of their coat colours, produced only 2-3\% of CBA spermatozoa. This indicates a strong selection operating against CBA germ cells. Germ-cell selection has been described also for chimaeras of other strain combinations (Mintz, 1968).

The frequency of misshapen sperm heads in adult males was chosen as an index of sperm quality because it is genetically determined, being significantly higher in KE than in CBA strain mice. The fact that the proportion of such heads is markedly elevated in pubertal males, irrespective of the strain (Krzanowska, 1981), may suggest that this characteristic is sensitive to influences exerted by adverse internal environment and thus could be modified in chimaeras. However, as shown in Fig. 7, in chimaeras producing only KE spermatozoa and in germ-line chimaeras, the distribution of sperm abnormality level, although shifted towards lower values, was clearly within the range characteristic of the KE strain, and most abnormal forms were also typical of that strain. This applied even to the germ-line chimaera No. 60 , with a preponderance of the CBA coat and with a 
considerable proportion of CBA Sertoli cells, as revealed by GPI analysis. For males producing exclusively CBA spermatozoa, the distribution of sperm abnormality level was typical of that strain, except for one $X X \leftrightarrow X Y$ chimaera which became sterile in later life. These results suggest that in normal conditions the level of sperm abnormalities is determined largely autonomously by germ-cell genotype, but may become elevated if the internal environment deteriorates beyond the range of 'normality', as in very young, senile or subfertile males.

A similar conclusion applies to efficiency of fertilization (Table 3). In matings with outbred females the percentage of fertilized ova, characteristic for the CBA or KE strain males, did not differ significantly for chimaeric males producing the same type of spermatozoa: again, one $\mathrm{XX} \leftrightarrow \mathrm{XY}$ chimaeric male with a lower level of fertilization, was probably in a subnormal condition because only few spermatozoa were found in the vasa deferentia at autopsy at 9 months of age.

The estimation of sperm competitive abilities in germ-line chimaeras could not be precise because of the very small percentages of CBA sperm cells involved. Nevertheless, the proportions of agouti progeny sired by germ-line chimaeras were significantly higher than expected from the percentages of CBA spermatozoa. In earlier experiments when $F_{1}$ females were inseminated with $\mathrm{KE}$ and $\mathrm{CBA}$ sperm mixtures, the proportions of agouti young in the resulting litters were $1 \cdot 5-1 \cdot 7$ times higher than the proportions of CBA spermatozoa in the mixture (Krzanowska, 1986). Although exact comparison of these data is not possible because more intermediate proportions of CBA spermatozoa (20-50\%) were then used, in both cases the CBA spermatozoa were more efficient. Differential survival of embryos is not likely to account for the surplus of progeny resulting from fertilization with the CBA spermatozoa because the difference between the number of young born ( $\sim 8$ per female) and the number of ova ovulated ( $\sim 9$ per female; Krzanowska, 1986$)$ is slight.

The higher competitive ability of CBA spermatozoa seems to depend on genes expressed through the germ line, because it appeared even in Males 45 and 46, containing somatic cells predominantly of $\mathrm{KE}$ origin, in which sperm cells could have higher chances of being developed under the influence of Sertoli cells derived from the KE than from the CBA component. Male 60, with a predominance of CBA coat colour and a considerable proportion of CBA Sertoli cells, deserves special attention. This male produced a proportion of CBA spermatozoa similar to those of the remaining 4 germ-line chimaeras $(2 \cdot 8 v s 2.0 \%)$ but sired significantly more agouti progeny ( 21 vs $4 \%$ ). One could therefore speculate that for full expression of their competitive abilities the CBA spermatozoa require environmental conditions created by CBA somatic (Sertoli?) cells, while $\mathrm{KE}$ somatic cells are inadequate in this respect. On the other hand, competitive abilities of the KE spermatozoa produced by Male 60 were apparently not improved, which indicates their genetic inferiority or inability to utilize the favourable environment created by CBA somatic cells. This again points to a largely autonomous determination of sperm quality.

B.W-Ś thanks Dr Anne McLaren, Mammalian Development Unit, University of London, for introducing the chimaera-producing techniques. We also thank Professor S. Stoklosowa for instruction and help in Sertoli cell isolation. This work was supported by he Polish Academy of Sciences within the project CPBP 05.05.

\section{References}

Bowman, P. \& McLaren, A. (1970) Viability and growth of mouse embryos after in vitro culture and fusion. $J$. Embryol. exp. Morph. 23, 693-704.

Burgoyne, P.S. (1975) Sperm phenotype and its relationship to somatic and germ line genotype: a study using mouse aggregation chimeras. Devl Biol. 44, 63-76.

Burgoyne, P.S., Buehr, M., Koopman, P., Rossant, J. \& McLaren, A. (1988) Cell-autonomous action of the testis-determining gene: Sertoli cells are exclusively XY in $\mathrm{XX} \leftrightarrow \mathrm{XY}$ chimaeric mouse testes. Development 102 , $443-450$.

Fulton, B.P. \& Whittingham, D.G. (1978) Activation of mammalian oocytes by intracellular injection of calcium. Nature, Lond. 273, 149-151.

Grootegoed, J.A., Oonk, R.B., Jansen, R. \& Van der Molen, H.J. (1985) Spermatogenic cells utilize metabolic intermediates from Sertoli cells. In Gamete Quality and Fertility Regulation, pp. 225-237. Eds R. 
Roland, M. J. Heineman, S. G. Hillier \& H. Vemer. Excerpta Medica. Elsevier Science Publishers B.V., Amsterdam.

Handel, M.A. (1987) Genetic control of spermatogenesis in mice. In Results and Problems in Cell Differentiation, 15 Spermatogenesis: Genetic Aspects, pp. 1-62. Ed. W. Hennig. Springer-Verlag, Berlin.

Handel, M.A., Washburn, L.L., Rosenberg, M.P. \& Eicher, E.M. (1987) Male sterility caused by $\mathrm{p}^{6 \mathrm{H}}$ and qk mutations is not corrected in chimeric mice. $J$. exp. Zool. 243, 81-92.

Harris, H. \& Hopkinson, D.A. (1976) Handbook of Enzyme Electrophoresis in Human Genetics. NorthHolland Publishing Corporation, Amsterdam.

Kierszenbaum, A.L. \& Tres, L.L. (1981) The structural and functional cycle of Sertoli cells in culture. In Bioregulators of Reproduction, pp. 207-228. Eds G. Jagiello \& H. J. Vogel. Academic Press, New York.

Krzanowska, H. (1969) Factor responsible for spermatozoan abnormality located on the $\mathrm{Y}$ chromosome in mice. Genet. Res. 13, 17-24.

Krzanowska, H. (1970) Relation between fertilization rate and penetration of eggs by supplementary spermatozoa in different mouse strains and crosses. $J$. Reprod. Fert. 22, 199-204.

Krzanowska, H. (1976) Inheritance of sperm head abnormality types in mice. The role of the $\mathrm{Y}$ chromosome. Genet. Res. 28, 189-198.

Krzanowska, H. (1981) Sperm head abnormalities in relation to age and strain of mice. J. Reprod. Fert. 62, 385-392.

Krzanowska, H. (1986) Interstrain competition amongst mouse spermatozoa inseminated in various proportions, as affected by the genotype of the $Y$ chromosome. J. Reprod. Fert. 77, 265-270.
Lenartowicz, M., Koszut, U. \& Wabik-Śliz, B. (1988) Application of C-band staining method for the analysis of XX/XY chimaeras in mice (Mus musculus). Genetica Polonica 29, 161-170.

Lyon, M.F., Glenister, P.H. \& Lamoreux, M.L. (1975) Normal spermatozoa from androgen-resistant germ cells of chimaeric mice and the role of androgen in spermatogenesis. Nature, Lond. 258, 620-622.

Mintz, B. (1968) Hermaphroditism, sex chromosomal mosaicism and germ cell selection in allophenic mice. J. Anim. Sci. (Suppl. 1) 27, 51-60.

Nakayama, H., Kuroda, H., Onoue, H., Fujita, J., Nishimune, Y., Matsumoto, K., Nagano, T., Suzuki, F. \& Kitamura, Y. (1988) Studies of $\mathrm{Sl} / \mathrm{Sl}^{\mathrm{d}} \leftrightarrow+/+$ mouse aggregation chimaeras. II. Effect of the steel locus on spermatogenesis. Development 102, 117-126.

Rafiński, J. \& Krzanowska, H. (1985) Electrophoretic variants of GPI and ICD in inbred strains of mice: $\mathrm{KE}, \mathrm{KP}, \mathrm{CBA} / \mathrm{Kw}$ and C57BL/Kw. Zwierzeta Lab. 22, 59-64.

Selander, R.K., Smith, M.H., Yang, S.Y., Johnson, W.E. \& Gentry, J.B. (1971) Biochemical polymorphism and systematics in the genus Peromyscus. I. Variation in the old-field mouse (Peromyscus polionotus). Univ. Texas Publ. 7103, 49-90.

Shaw, C.R. \& Prasad, R. (1970) Starch gel electrophoresis of enzymes - a compilation of recipies. Biochem. Genet. 4, 297-320.

Whittingham, D.G. (1971) Culture of mouse ova. $J$. Reprod. Fert., Suppl. 14, 7-21.

Received 8 August 1990 